\title{
Turgor Closely Relates to Postharvest Fruit Softening and Can Be a Useful Index to Select a Parent for Producing Cultivars with Good Storage Potential in Apple
}

\author{
Hiroshi Iwanami ${ }^{1}$, Shigeki Moriya, Nobuhiro Kotoda, \\ and Kazuyuki Abe \\ Apple Breeding and Physiology Research Team, National Institute of Fruit \\ Tree Science, Shimo-kuriyagawa, Morioka 020-0123, Japan
}

Additional index words. Malus $\times$ domestica, cultivar difference, firmness, mealiness, shelf life quantitative method for measuring the degree of cell separation by shaking tissue discs in a sucrose solution. This method can only detect the contribution of cell separation to tissue failure. Using this method, Iwanami et al. (2008) revealed that the occurrence and development of mealiness (cell separation) were considered to involve major genes and that apple genotypes could be divided into two types, mealy and nonmealy.

Previous studies concerned with the mechanism of softening have been undertaken with a single or a few cultivars without any distinction between mealy and nonmealy genotypes. Moreover, although a reduction in cell turgor may contribute to loss of firmness during storage, turgor was measured only one or two times during storage, and observations of the relationships between firmness and turgor have been limited to the time immediately after storage. Therefore, the objectives of this study were to reveal the relationships between change in turgor and softening during storage considering the occurrence of mealiness.

\section{Materials and Methods}

Fruit materials and storage conditions. Twenty-seven apple cultivars from an orchard at the Apple Research Station at the National Institute of Fruit Tree Science (NIFTS), Japan, were selected on the basis of diversity of the harvest date. The cultivars were used as parents in the NIFTS applebreeding programs. Twenty fruit were picked randomly from a tree when most of the fruit were determined to be mature on the basis of ground color, texture, flavor, and starch staining from 19 and 26 of the 27 cultivars in 2006 and 2007, respectively (Table 1). After weighing, the fruit were stored in a chamber controlled at $20{ }^{\circ} \mathrm{C}$ and $85 \%$ relative humidity (RH). The next morning, four of the stored fruit were removed from the chamber to measure the fruit characteristics as harvest values. The measurements were performed with four of the remaining fruit at 5, 10, 20, and $30 \mathrm{~d}$ after the first sampling.

Measurement of flesh firmness, mealiness, and turgor. Flesh firmness was measured using a penetrometer (FT327; McCormick Fruit Technology, Yakima, WA) mounted on a drill press and fitted with an 11.1-mm probe on the pared surfaces of the sunny and shady sides of each fruit.

Mealiness was measured according to Iwanami et al. (2005). Ten discs (10 $\mathrm{mm}$ in diameter, $5 \mathrm{~mm}$ in thickness) were taken from $10 \mathrm{~mm}$ below the skin of the equatorial region of all sides of each fruit with a cork borer, infiltrated with a $12 \%$ sucrose solution under a vacuum, filtered with gauze, and weighed. The discs were transferred to a test tube (diameter $30 \mathrm{~mm}$ ) containing $10 \mathrm{~mL}$ of the sucrose solution and shaken for $8 \mathrm{~h}\left(20^{\circ} \mathrm{C}\right.$, $180 \mathrm{rpm}, 3-\mathrm{cm}$ wide shake; PLUS SHAKER EP-1, TAITEC, Tokyo). The degree of mealiness was calculated as $(\mathrm{Wi}-\mathrm{Ws}) / \mathrm{Wi} \times$ $100(\%)$, where $\mathrm{Wi}$ and $\mathrm{Ws}=$ weight of discs before and after shaking, respectively.

\footnotetext{
Received for publication 12 Mar. 2008. Accepted for publication 28 Apr. 2008.

${ }^{1}$ To whom reprint requests should be addressed; e-mail hiwanami@affrc.go.jp
} and a convenient method for evaluating mealiness objectively is not yet available. Because mealiness is characterized by weak strength of adhesion between neighboring cells, Motomura et al. (2000) proposed a 


\begin{tabular}{|c|c|c|c|c|c|c|c|c|}
\hline \multirow[b]{2}{*}{ Cultivar } & \multirow[b]{2}{*}{$\begin{array}{c}\text { Abbreviation } \\
\text { in Figure } 1\end{array}$} & \multirow[b]{2}{*}{ Parentage } & \multicolumn{3}{|c|}{2006} & \multicolumn{3}{|c|}{2007} \\
\hline & & & $\begin{array}{c}\text { Harvest } \\
\text { date }\end{array}$ & $\begin{array}{l}\text { Firmness } \\
(\mathrm{N})\end{array}$ & $\begin{array}{l}\text { Starch } \\
\text { index }^{z}\end{array}$ & $\begin{array}{c}\text { Harvest } \\
\text { date }\end{array}$ & $\begin{array}{l}\text { Firmness } \\
\text { (N) }\end{array}$ & $\begin{array}{l}\text { Starch } \\
\text { index }^{z}\end{array}$ \\
\hline Chinatsu & $\mathrm{CNT}$ & Akane $\times$ Earliblaze & & & & 16 Aug. & 72.1 & 2.7 \\
\hline $\begin{array}{l}\text { American Summer } \\
\text { Pearmain }\end{array}$ & ASP & Unknown & & & & 30 Aug. & 65.8 & 2.6 \\
\hline Sansa & SNS & Gala $\times$ Akane & 14 Sept. & 53.2 & 1.7 & 6 Sept. & 63.7 & 2.7 \\
\hline Kiou & $\mathrm{KIO}$ & Orin $\times$ Senshu & & & & 6 Sept. & 82.2 & 3.9 \\
\hline Akane & $\mathrm{AKN}$ & Jonathan $\times$ Worcester Pearmain & 14 Sept. & 67.2 & 1.3 & 13 Sept. & 69.7 & 1.1 \\
\hline Tsugaru & TGR & Golden Delicious $\times$ Jonathan & 21 Sept. & 45.5 & 1.3 & 13 Sept. & 54.9 & 2.1 \\
\hline McIntosh & $\mathrm{MC}$ & Unknown & 21 Sept. & 50.4 & 2.9 & 20 Sept. & 56.8 & 2.4 \\
\hline Hatsuaki & HTA & Jonathan $\times$ Golden Delicious & 28 Sept. & 58.2 & 0.6 & 20 Sept. & 64.1 & 1.6 \\
\hline Royal Gala & GAL & Kidd's Orange $\times$ Golden Delicious & & & & 27 Sept. & 68.4 & 0.9 \\
\hline Silken & SLK & Honeygold $\times$ Sunrise & 28 Sept. & 61.3 & 2.9 & 27 Sept. & 71.2 & 3.7 \\
\hline Senshu & SSU & Toko $($ Golden Delicious $\times$ Indo $) \times$ Fuji & 5 Oct. & 64.2 & 1.9 & 4 Oct. & 59.7 & 1.7 \\
\hline Macoun & $\mathrm{MCN}$ & McIntosh $\times$ Jersey Black & 5 Oct. & 76.3 & 3.2 & & & \\
\hline Red Gold & RG & Golden Delicious $\times$ Richared Delicious & & & & 4 Oct. & 70.6 & 4.0 \\
\hline Jonathan & JT & Unknown & 12 Oct. & 72.9 & 2.5 & 11 Oct. & 68.5 & 2.3 \\
\hline Kitaro & KIT & Hatsuaki $\times$ Fuji & 12 Oct. & 66.8 & 1.8 & 11 Oct. & 60.2 & 4.0 \\
\hline Jonagold & JG & Golden Delicious $\times$ Jonathan & 19 Oct. & 65.9 & 1.3 & 18 Oct & 77.3 & 2.5 \\
\hline Starking Delicious & SD & Sport of Delicious & 19 Oct. & 59.8 & 2.6 & 18 Oct. & 54.2 & 2.1 \\
\hline Golden Delicious & GD & Unknown & 26 Oct. & 59.2 & 1.9 & 25 Oct. & 70.6 & 1.9 \\
\hline Megumi & MG & Ralls Janet $\times$ Jonathan & & & & 25 Oct. & 57.9 & 2.5 \\
\hline Kotaro & KOT & Hatsuak $\times$ Fuji & 26 Oct. & 75.7 & 2.1 & 1 Nov. & 74.8 & 1.8 \\
\hline Shinano Gold & SG & Golden Delicious $\times$ Senshu & 2 Nov. & 68.2 & 1.6 & 1 Nov. & 68.1 & 1.7 \\
\hline Orin & OR & Golden Delicious $\times$ Indo & 9 Nov. & 65.9 & 2.0 & 8 Nov & 65.1 & 2.1 \\
\hline Fuji & FJ & Ralls Janet $\times$ Delicious & 9 Nov. & 76.3 & 1.8 & 8 Nov. & 67.5 & 1.6 \\
\hline Indo & IND & Unknown & 16 Nov. & 90.9 & 3.0 & 15 Nov. & 84.3 & 3.0 \\
\hline Ralls Janet & RJ & Unknown & 16 Nov. & 75.4 & 1.0 & 15 Nov. & 70.3 & 1.4 \\
\hline Braeburn & $\mathrm{BB}$ & Lady Hamilton $\times$ unknown & & & & 22 Nov. & 92.1 & 1.3 \\
\hline Pink Lady & PL & Golden Delicious $\times$ Lady Williams & & & & 22 Nov. & 93.3 & 2.5 \\
\hline
\end{tabular}

${ }^{2}$ Starch staining by iodine solution was rated from $0=0 \%$ staining to $5=100 \%$ staining.

The turgor was determined using a thermocouple psychrometer (SC-10A; Decagon Devices, Pullman, WA) in a room controlled at $20{ }^{\circ} \mathrm{C}$. Because the accuracy of a measurement with the instrument can also be affected by low $\mathrm{RH}$, the room was controlled at $75 \%$ RH. Two discs $(14.5 \mathrm{~mm}$ in diameter, $4 \mathrm{~mm}$ in thickness) were taken from $10 \mathrm{~mm}$ below the skin of the equatorial region of each fruit with a cork borer and placed on the bottom of the psychrometer sampling cup immediately after excision. The surface of the discs was wiped off with tissue paper. After measuring the water potential of the individual discs, each sample cup was sealed and frozen at $-80{ }^{\circ} \mathrm{C}$ and thawed at $20{ }^{\circ} \mathrm{C}$. When temperature equilibrium was achieved, the osmotic potential $\left(\psi_{\mathrm{S}}\right)$ was measured for the same sample. Data were obtained as microvolts and converted to MPa based on a calibration curve using $\mathrm{NaCl}$ standards. The turgor potential was calculated by subtracting the $\psi_{\mathrm{S}}$ from the water potential.

\section{Results}

Changes in firmness, turgor, and degree of mealiness in the flesh during storage varied among cultivars. According to the relationships among change in firmness, turgor, and mealiness, the cultivars were divided into five groups: 1) fruit that softened rapidly within $10 \mathrm{~d}$ of harvest, turgor continued to decrease throughout storage, and mealiness occurred and developed at an extreme rate for $20 \mathrm{~d}$ (Fig. 1A); 2) fruit that softened within $20 \mathrm{~d}$, turgor decreased rapidly within $20 \mathrm{~d}$, but no further decrease was observed during the rest of the storage period, and mealiness occurred and developed (Fig. 1B); 3) fruit that softened within $20 \mathrm{~d}$, turgor decreased within $20 \mathrm{~d}$, but no more decrease was observed during the rest of the storage period, and mealiness occurred but did not develop (Fig. 1C); 4) fruit that softened relatively slowly, turgor continued to decrease throughout storage, and slight mealiness occurred at the end of the storage period (Fig. 1D); and 5) fruit that did not soften significantly, turgor continued to decrease throughout storage, and mealiness hardly occurred (Fig. 1E). Considering the occurrence and development of mealiness exclusively, distinct segregation was observed at $30 \mathrm{~d}$ of storage between the cultivars in groups A-B and C-E in Figure 1. The cultivars in groups A-B can be defined as mealy.

Although the measurements of firmness at harvest in the cultivars in group D were above $70 \mathrm{~N}$ and higher than those in groups $\mathrm{C}$ and $\mathrm{E}$, except for 'Pink Lady,' the measurements of turgor at harvest in the cultivars in group D were not always higher than those in groups $\mathrm{C}$ and $\mathrm{E}$ (Fig. 1). Moreover, although the measurements of firmness at $30 \mathrm{~d}$ of storage in the cultivars in group A were below $40 \mathrm{~N}$ and lower than those in groups D and $\mathrm{E}$, the measurements of turgor at $30 \mathrm{~d}$ of storage in the cultivars in group A were from 0.1 to 0.2 $\mathrm{MPa}$ and almost the same as those in groups $\mathrm{D}$ and $\mathrm{E}$. Therefore, the value of turgor itself did not seem to determine the measurement of firmness. Although the degrees of reduction in turgor and firmness during storage varied among cultivars, the periods of the reduction in firmness were almost the same as those of the reduction in turgor, and softening seemed to accompany the reduction in turgor in most cultivars, except for those in group A. In the cultivars in Figure 1A, firmness decreased within $10 \mathrm{~d}$ with the decrease in turgor, but the decrease in firmness slowed down after 10 $\mathrm{d}$ despite the continuous decrease in turgor.

Because softening occurred with the reduction of turgor for at least $10 \mathrm{~d}$ in almost all cultivars, the genotypic difference and relationship between softening and the reduction of turgor were evaluated by comparing the rates of the reduction of firmness and turgor for $10 \mathrm{~d}$. The rates of the reduction of firmness and turgor were obtained by applying a linear regression to the changes in firmness and turgor, respectively. Individual fruit data for each sampling, not mean value of each sampling fruit, were used for the application of the linear regression. In the cultivars in group E in Figure 1 (nonmealy, nonsoftening), the softening rates were all low, and the reduction rates of turgor were also low (Fig. 2 ). On the other hand, the softening rates of the cultivars in groups A and B (mealy) were all high, but the reduction rates of turgor varied widely. The softening rates of 'Starking Delicious' and 'Macoun' were high, but the reduction rates of turgor were nearly identical to those of the nonsoftening group cultivars Fuji or Senshu. The softening rates of the cultivars in groups C and D (nonmealy, softening) were intermediate, and the reduction rates of turgor were higher than those of the cultivars in group E. The softening rates were significantly correlated with the reduction rates of turgor in nonmealy cultivars. 

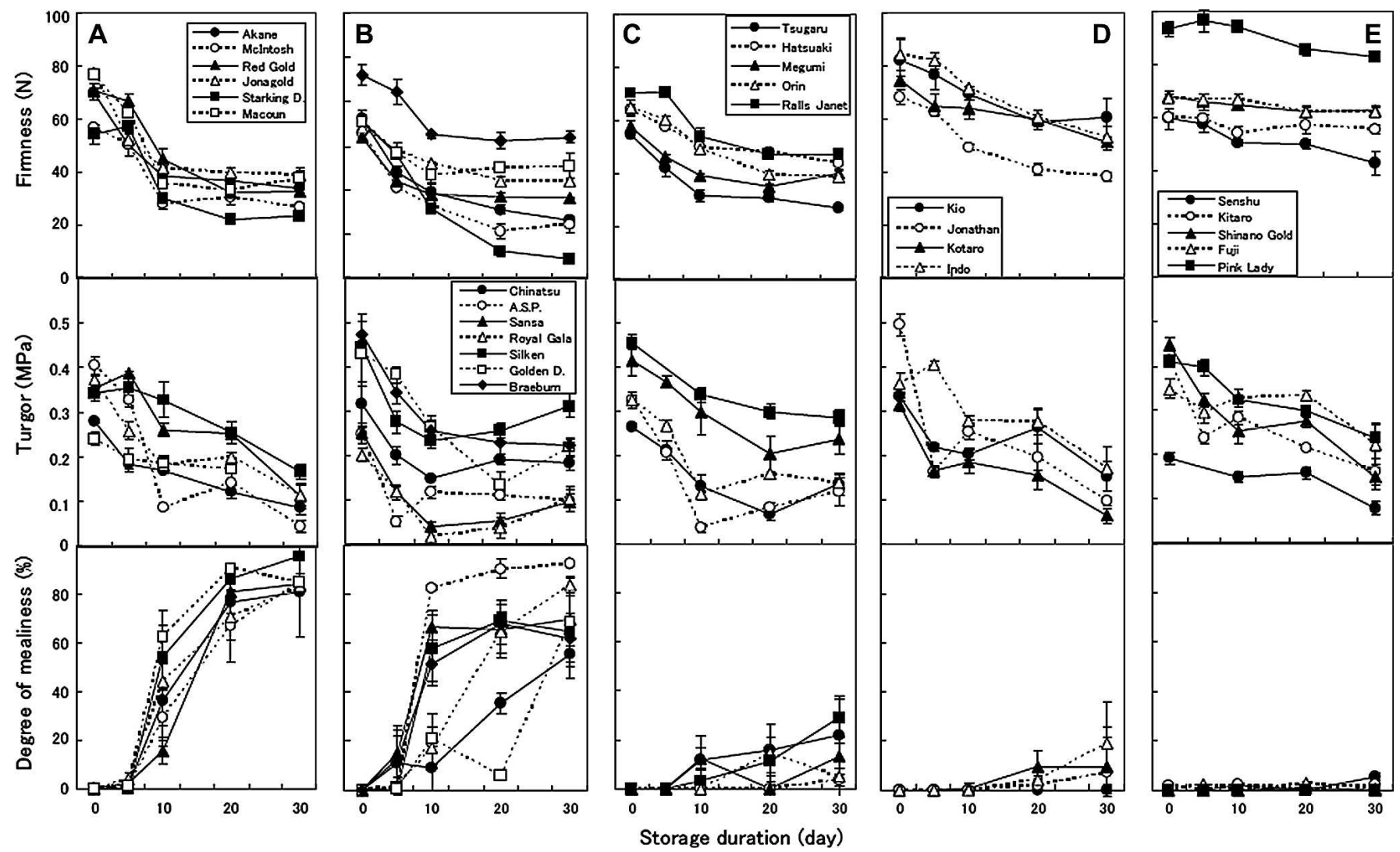

Fig. 1. Changes in flesh firmness, turgor, and degree of mealiness in 27 apple cultivars during storage at $20{ }^{\circ} \mathrm{C}, 85 \%$ relative humidity. The data were collected in 2007 for all cultivars except 'Macoun'. (A) Fruit that softened rapidly for $10 \mathrm{~d}$; turgor continued to decrease throughout storage; and extreme mealiness occurred and continued to develop for $20 \mathrm{~d}$. (B) Fruit that softened within $20 \mathrm{~d}$; turgor decreased rapidly for 10 or $20 \mathrm{~d}$; and mealiness occurred and developed. (C) Fruit that softened for $20 \mathrm{~d}$; turgor decreased for $20 \mathrm{~d}$; and mealiness occurred but did not develop. (D) Fruit that softened relatively slowly; turgor continued to decrease throughout storage; and some mealiness occurred late in storage. (E) Fruit that did not decrease significantly; turgor continued to decrease throughout storage; and mealiness was slight. Vertical bars represent SE of four fruit replications.

The measurements of turgor were not always higher or lower in mealy cultivars than nonmealy cultivars at harvest or at the end of storage (Fig. 1), indicating that the value of turgor itself also did not determine the occurrence of mealiness. However, the degrees of mealiness at $30 \mathrm{~d}$ of storage were influenced by the reduction rates of turgor. When the reduction of turgor after harvest was slow, mealy cultivars tended to develop severe mealiness during storage. Significant negative relationships were observed between the degrees of mealiness at $30 \mathrm{~d}$ of storage and the reduction rates of turgor in mealy cultivars (Fig. 3).

Twelve cultivars (Sansa, Kiou, Tsugaru, Hatsuaki, Red Gold, Kitaro, Jonagold, Megumi, Kotaro, Shinano Gold, Orin, and Fuji) have resulted from the crosses between the cultivars used in this study, assuming that three sport cultivars, Starking Delicious, Richared Delicious, and Royal Gala, are the same as the original cultivars Delicious and Gala. The reduction rates of turgor in the 12 cultivars were significantly correlated with the mean reduction rates of turgor in those parent cultivars (Fig. 4A). The regression coefficient was $1.01 \pm 0.26$, indicating that the value of the reduction rate of turgor in a progeny cultivar was close to the mean value of those in its parents. Significant relation- ships were also observed between the softening rates of the progeny cultivars and those of their parents (Fig. 4B), but the regression coefficient $(1.33 \pm 0.52)$ was far from 1.0 because there were outliers ('Jonagold', 'Shinano Gold', and 'Fuji') and the effect of the outliers on the regression line was very large.

\section{Discussion}

Softening was closely related with changes in turgor because the reduction in turgor slowed during storage accompanied slow softening in most cultivars (Fig. 1). The value of turgor itself, however, did not seem to determine the measurement of firmness and occurrence of mealiness. Tong et al. (1999) compared puncture firmness with cell turgor after 6 months of cold storage and indicated that the fruit of 'Honeycrisp' and 'Delicious' were firmer and had higher turgor than those of 'Honeygold' and 'Macoun'. Therefore, they suggested that there were positive relationships between firmness and turgor. However, the fruit of 'Honeygold' after 3 months of cold storage were as firm as those of 'Delicious' and firmer than those of 'Macoun' but had as low turgor as that of 'Macoun'. Therefore, the relationship between the values of firmness and turgor could depend on the storage period.
The softening rates and reduction rates of turgor during $10 \mathrm{~d}$ of storage at $20{ }^{\circ} \mathrm{C}$ were continuously distributed among the cultivars tested (Fig. 2). Softening is a process primarily associated with changes in the cell walls of parenchyma cells, which result in tissue failure (Harker et al., 1997). As fruit soften, tissue failure predominantly occurs first by cell fracture, then by cell rupture, and finally by cell-to-cell debonding (Harker et al., 2002). Harker et al. (2006) observed that fruit of 'Pacific Rose' did not soften during long storage and the failure modes of the fruit were mainly cell fracture both at harvest and after storage. The fruit of 'Jazz' softened by $\approx 10 \%$ to $20 \%$ of firmness during storage, showing that the failure modes of the fruit were mainly cell fracture at harvest but cell rupture exclusively after storage. In our study, although a significant positive relationship was observed between both rates in nonmealy cultivars, the cultivars in which the reduction rates of turgor were from 0.010 to $0.014 \mathrm{MPa} \cdot \mathrm{d}^{-1}$ had a relatively wide range of softening rates from 0.3 to $2.5 \mathrm{~N} \cdot \mathrm{d}^{-1}$ (Fig. 2). Our results, therefore, suggested that tissue failure could occur by cell fracture exclusively and by cell rupture in nonmealy fruit with a reduction rate of turgor lower than $0.010 \mathrm{MPa} \cdot \mathrm{d}^{-1}$ and higher than $0.014 \mathrm{MPa} \cdot \mathrm{d}^{-1}$, respectively. The range between 0.010 and $0.014 \mathrm{MPa} \cdot \mathrm{d}^{-1}$ can 


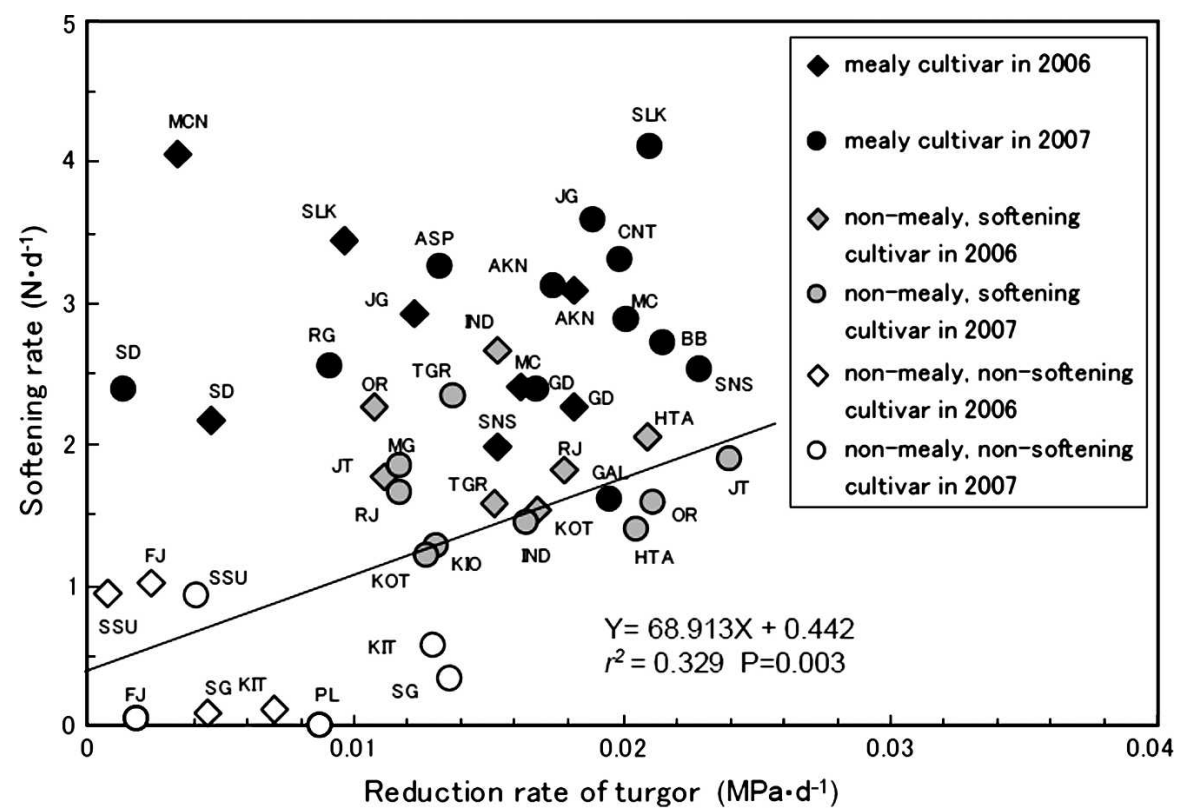

Fig. 2. Relationship between the reduction rates of turgor and the softening rates in 27 apple cultivars stored at $20^{\circ} \mathrm{C}$. The letters with each symbol are an abbreviation of the cultivar. The cultivars were divided into three groups according to the relationship between change in firmness and mealiness as shown in Figure 1. The mealy cultivar, nonmealy and softening cultivar, and nonmealy and nonsoftening cultivar belong to groups A to B, C to D, and E in Figure 1, respectively. The solid line represents the regression equation calculated using data of nonmealy cultivars.

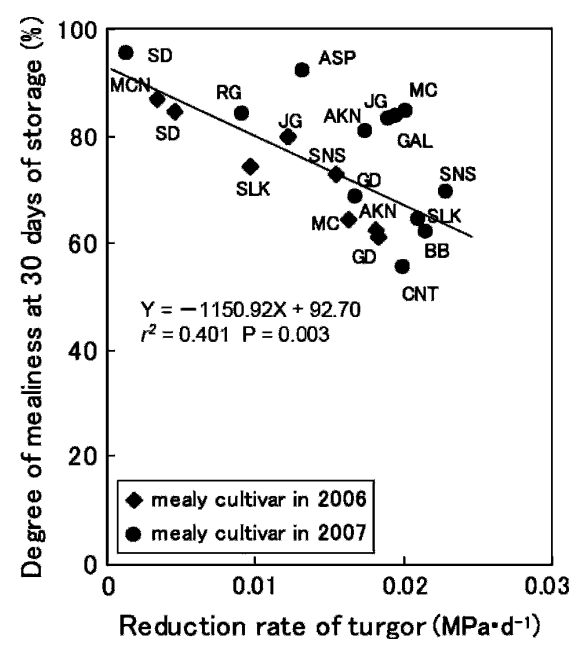

Fig. 3. Relationship between the reduction rate of turgor and the degree of mealiness at $30 \mathrm{~d}$ of storage in 13 mealy apple cultivars stored at $20{ }^{\circ} \mathrm{C}$. The letters with each symbol are the abbreviation of the cultivar. The solid line represents the regression equation.

be defined as a period of transition, and both cell fracture and rupture may occur at various ratios depending on fruit conditions.

The softening rates of mealy cultivars were all high and over $\approx 2 \mathrm{~N} \cdot \mathrm{d}^{-1}$ in most cultivars, although the reduction rates of turgor varied widely (Fig. 2). The high softening rates were consistent with the results by Iwanami et al. (2005), indicating that the softening rates of mealy cultivars were all high irrespective of the degree of mealiness. Harker et al. (2006) also observed that fruit that softened markedly during
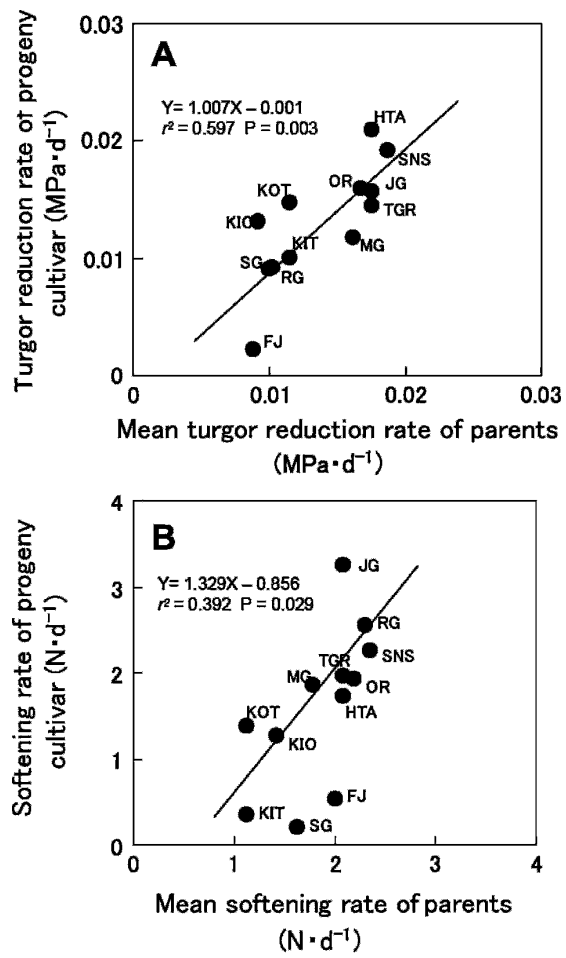

Fig. 4. Relationship between the mean value of parents and the value of their progeny cultivar (A) in the reduction rate of turgor and (B) in the softening rate of 12 apple cultivars. The values of the progeny and parent cultivar are averaged for 2 years when applicable. The solid line represents the regression equation.

storage failed by cell-to-cell debonding. What was rather surprising in our study is that there were cultivars with a low reduction rate of turgor. It seems, however, natural for mealy cultivars to retain relatively high turgor after harvest because high turgor could cause cells to swell, resulting in a reduction of the cell-to-cell contact area (Harker and Hallett, 1992). In fact, a negative relationship was observed between the degree of mealiness at $30 \mathrm{~d}$ of storage and the reduction rate of turgor in mealy cultivars (Fig. 3), indicating that the smaller the change in turgor after harvest, the larger the degree of mealiness developing during storage. The reduction rates of turgor in the mealy cultivars Starking Delicious and Macoun were nearly identical to those in cultivars that had barely softened during storage in our experiment. This possibly means that the strength of adhesion between neighboring cells determines the fate of a cultivar that has a low reduction rate of turgor whether the cultivar has severe mealiness or long shelf life. On the other hand, there were mealy cultivars with high reduction rates of turgor, suggesting that tissue can also fail by cell rupture at high ratios, although the tissue mainly failed by cell-to-cell debonding. The fruit of the mealy cultivar Braeburn softened with a high reduction rate of turgor (Fig. 2). Harker and Hallett (1992) indicated that $20 \%$ of low- and $80 \%$ of high-maturity fruit became mealy after 16 weeks storage at $0{ }^{\circ} \mathrm{C}$ in 'Braeburn' and Harker et al. (2002) also observed that fruit of 'Braeburn' failed very easily as a result of cell rupture although the fruit was firm $(72 \mathrm{~N})$.

Heritability of the softening rate has been estimated to be high $\left(\mathrm{h}^{2}=0.93\right)$ (Iwanami et al., 2008). High heritability means that progeny closely resembles its parents in a phenotypic value (softening rate). The resemblance can be displayed by parent-progeny regression. In this study, the relationships between the progeny cultivars and their parents regarding the softening rate were significant at the $5 \%$ level, but there were outliers (Fig. 4B). The softening rate of 'Jonagold' was considerably higher than that of its parents, and the softening rates of 'Fuji' and 'Shinano Gold' were considerably lower than those of their parents. Iwanami et al. (2008) indicated that the softening rates of mealy progeny tend to shift higher than the mean values of the softening rates of their parents. Therefore, the mealy cultivar Jonagold showed a remarkably higher softening rate than its parents. On the other hand, one of the parents of 'Fuji' and 'Shinano Gold' is a mealy cultivar with the result that its parents also probably showed a remarkably higher softening rate than the nonmealy progenies 'Fuji' and 'Shinano Gold'. Iwanami et al. (2008) also indicated that the contribution of a mealy parent to the softening rate of nonmealy progenies cannot be predicted by its phenotypic value (softening rate). In contrast to the softening rate, the relationships between progeny cultivars and their parents in the reduction rate of turgor were highly significant $(P=0.003)$, and the regression coefficient was 1.01 , which indicated that progeny cultivars closely resembled its parents and the reduction rate of turgor could be 
considered to be the character with the higher heritability (Fig. 4A).

Iwanami et al. (2008) proposed the softening rate as a phenotypic value and estimated the heritability and the breeding value of softening to produce a new cultivar with good storage and shelf life potential. They also indicated that it was necessary to estimate the breeding value in mealy cultivars because the softening rates (phenotypic values) could be influenced by the occurrence of mealiness and were inconsistent with the breeding values in mealy cultivars. That is, mealy cultivars can produce a nonmealy progeny, but the softening rate of the nonmealy progeny cannot be predicted from the softening rates of the mealy parents. To estimate the breeding values, many progenies have to be made, and it takes time and labor. On the contrary, the reduction rate of turgor does not relate to the occurrence of mealiness and seems to be a better index than the softening rate to select a parent for producing cultivars with good storage potential. The softening rate of a progeny from a cross between parents with a low reduction rate of turgor can be predicted to be low unless the progeny develops mealiness. A cultivar with a reduction rate of turgor below $0.01 \mathrm{MPa} \cdot \mathrm{d}^{-1}$, although the cultivar can be mealy, has the potential for producing a progeny with good storage potential such as 'Fuji' which has a long storage potential.

Because textural attributes are determined by the structural, physiological, and biochemical characteristics of cells, many studies have tried to clarify the mechanism of softening at the cellular levels by investigating the changes in the pectin composition of cell walls and the activity of cell wallmodifying enzymes (Glenn and Poovaiah, 1990; Nara et al., 2001; Pena and Carpita, 2004; Tong et al., 1999; Yoshioka et al., 1995). Recently, Vicente et al. (2007) identified several tomato mutants whose fruit exhibit exceptional shelf life, remaining firm and maintaining an edible texture for many months after reaching a fully ripe stage. Cell wall degradation and cell separation of the fruit occurred to the same extent and at the same rate in these mutants, as in normally softening fruit. However, cellular turgor remained high in them, unlike normally softening fruit. These results suggest that wall disassembly is not the sole and primary cause of fruit softening and that turgor is critically important. In our study, cultivars with good shelf life had low reduction rates of turgor, but cell separation could occur independently of the rate of reduction in turgor. Therefore, further studies are required to elucidate factors that can influence turgor and determine the relationship between these factors and softening. One of the factors may be water loss from fruit. However, cultivar differences in weight loss (equivalent to water loss) of fruit during storage did not relate to those in the softening rate and the reduction rate of turgor in our study (data not shown).

In conclusion, fruit softened with a reduction in turgor in almost all cultivars for $10 \mathrm{~d}$ of storage at $20^{\circ} \mathrm{C}$. The softening rates were significantly correlated with the reduction rates of turgor in nonmealy cultivars, and the reduction rates of turgor were all low in cultivars that barely softened in storage. The softening rates of mealy cultivars were all high, but the reduction rates of turgor varied widely. Furthermore, there were cultivars showing low reduction rates of turgor, which were almost identical to those of cultivars that barely softened in storage. Because the reduction rates of turgor in progeny cultivars were consistent with the mean reduction rates of turgor in their parents, a cultivar with a low reduction rate of turgor, although the cultivar can be mealy, has the potential to produce a progeny with a low reduction rate of turgor that has good storage potential.

\section{Literature Cited}

De Smedt, V., E. Pauwels, J. De Baerdemaeker, and B. Nicolai. 1998. Microscopic observation of mealiness in apple: A quantitative approach. Postharvest Biol. Technol. 14:151-158.

Glenn, G.M. and B.W. Poovaiah. 1990. Calciummediated postharvest changes in texture and cell wall structure and composition in 'Golden Delicious' apples. J. Amer. Soc. Hort. Sci. 115:962-968.

Harker, F.R. and I.C. Hallett. 1992. Physiological changes associated with development of mealiness of apple fruit during storage. HortScience 27:1291-1294.

Harker, F.R., J. Maindonald, S.H. Murray, F.A. Gunson, I.C. Hallett, and S.B. Walker. 2002. Sensory interpretation of instrumental measurements 1: Texture of apple fruit. Postharvest Biol. Technol. 24:225-239.

Harker, F.R., R.J. Redgwell, I.C. Hallett, S.H. Murray, and G. Carter. 1997. Texture of fresh fruit, p. 121-224. In: J. Janick (ed.). Horticultural Reviews, vol. 20. Wiley, New York.

Harker, F.R., A. White, F.A. Gunson, I.C. Hallett, and H.N. De Silva. 2006. Instrumental measurement of apple texture: A comparison of the single-edge notched bend test and the penetrometer. Postharvest Biol. Technol. 39:185192.

Hatfield, S.G.S. and M. Knee. 1988. Effects of water loss on apples in storage. Int. J. Food Sci. Technol. 23:575-583.

Iwanami, H., S. Moriya, N. Kotoda, S. Takahashi, and $\mathrm{K}$. Abe. 2005. Influence of mealiness on the firmness of apples after harvest. HortScience 40:2091-2095.

Iwanami, H., S. Moriya, N. Kotoda, S. Takahashi, and K. Abe. 2008. Estimations of heritability and breeding value for postharvest fruit softening in apple. J. Amer. Soc. Hort. Sci. 133: 92-99.

Lapsley, K.G., F.E. Escher, and E. Hoehn. 1992. The cellular structure of selected apple varieties. Food Structure 11:339-349.

Lin, T.-T. and R.E. Pitt. 1986. Rheology of apple and potato tissue as affected by cell turgor pressure. J. Texture Stud. 17:291-313.

Motomura, Y., J. Takahashi, and K. Nara. 2000. Quantitative measurement of mealiness in apple flesh. Bull. Fac. Agr. Life Sci. Hirosaki Univ. 3:23-28.

Nara, K., Y. Kato, and Y. Motomura. 2001. Involvement of terminal-arabinose and -galactose pectic compounds in mealiness of apple fruit during storage. Postharvest Biol. Technol. 22: $141-150$.

Pena, M.J. and N.C. Carpita. 2004. Loss of highly branched arabinans and debranching of rhamnogalacturonan I accompany loss of firm texture and cell separation during prolonged storage of apple. Plant Phyiol. 135:13051313.

Saftner, R., W.S. Conway, and C.E. Sams. 1998 Effect of postharvest calcium chloride treatments on tissue water relations, cell wall calcium levels and postharvest life of 'Golden Delicious' apples. J. Amer. Soc. Hort. Sci. 123:893-897.

Tong, C., D. Krueger, Z. Vickers, D. Bedford, J. Luby, A. El-Shiekh, K. Shackel, and H. Ahmadi. 1999. Comparison of softening-related changes during storage of 'Honeycrisp' apple, its parent, and 'Delicious'. J. Amer. Soc. Hort. Sci. 124:407415.

Vicente, A.R., M. Saladie, J.K.C. Rose, and J.M. Labavitch. 2007. The linkage between cell wall metabolism and fruit softening: Looking to the future. J. Sci. Food Agr. 87:14351448 .

Yoshioka, H., Y. Kashimura, and K. Kaneko. 1995. $\beta$-D-galactosidase and $\alpha$-L-arabinofuranosidase activities during the softening of apples. J. Jpn. Soc. Hort. Sci. 63:871-878. 